\title{
Lake-Based Nursery Rearing of Nile Tilapia (Oreochromis niloticus) Fingerlings in Nylon Hapas: Effects of Stocking Density on Growth, Survival and Profitability
}

\author{
Amos Asase1, Francis Kofi Ewusie Nunoo², Felix Yao Klenam Attipoe ${ }^{3}$ \\ ${ }^{1}$ Department of Fisheries and Water Resources, University of Energy and Natural Resources, Sunyani, Ghana \\ ${ }^{2}$ Department of Marine and Fisheries Sciences, University of Ghana, Legon, Ghana \\ ${ }^{3}$ CSIR/Water Research Institute, Aquaculture Research and Development Centre, Akosombo, Ghana \\ Email: amos.asase@uenr.edu.gh
}

How to cite this paper: Asase, A., Nunoo, F.K.E. and Attipoe, F.Y.K. (2016) LakeBased Nursery Rearing of Nile Tilapia (Oreochromis niloticus) Fingerlings in Nylon Hapas: Effects of Stocking Density on Growth, Survival and Profitability. Agricultural Sciences, 7, 660-669. http://dx.doi.org/10.4236/as.2016.710062

Received: September 2, 2016

Accepted: October 22, 2016

Published: October 25, 2016

Copyright $\odot 2016$ by authors and Scientific Research Publishing Inc. This work is licensed under the Creative Commons Attribution International License (CC BY 4.0).

http://creativecommons.org/licenses/by/4.0/ (c) (i) Open Access

\section{Abstract}

The inadequate supply of tilapia fingerling is a major limitation to cage culture development in Ghana. Lake-based hapa systems are very efficient in nursing fingerlings although the process can be tricky due to inherent effects of stocking densities and environmental factors. This study aimed at assessing the growth, survival and profitability of Nile tilapia (Oreochromis niloticus) fingerlings of the Akosombo strain reared in nine $1 \mathrm{~m}^{3}$ Lake-based hapas at different densities. Each hapa was stocked with $2.12 \pm 0.14 \mathrm{~g}$ sex-reversed tilapia fingerlings at varying stocking densities of $400 \mathrm{fish} / \mathrm{m}^{3}, 800 \mathrm{fish} / \mathrm{m}^{3}$ and $1200 \mathrm{fish} / \mathrm{m}^{3}$ serving as treatments T1, T2 and T3 respectively. Each treatment was replicated thrice. Bi-weekly samplings were done and water quality parameters were measured. After the experiment, analysis of variance showed significant differences $(p<0.05)$ in the weight gained, specific growth rate, profit index and feed conversion ratio among treatments. The T1 fingerlings exhibited the highest specific growth rate (3.28 $\pm 0.10 \% /$ day) and FCR (1.42 \pm 0.09$)$ than others. Overall, profit index was affected by stocking density and varied significantly between treatments. Treatment T3 was found to be better for commercial fingerling production because survival rate $(91.14 \pm 3.23 \%)$ and profit index $(3.96 \pm$ $0.24)$ were the highest while treatment $\mathrm{T} 1$ recorded the least index of $1.31 \pm 0.10$. Survival rates ranged between $89 \%$ and $91 \%$ but no statistical differences were observed among treatments. It is concluded that the stocking densities used had significant effects on the specific growth rate, gain in weight and feed conversion ratio of fingerlings reared in Lake-based hapas. However, in fingerling production, not only profit but also rapid growth needs consideration, hence, T2 is highly recommended 
for nursery rearing of tilapia fingerlings in this system due to the relatively high profit index, growth rate and survival.

\section{Keywords}

Hapa, Fingerlings, Stocking, Density, Tilapia

\section{Introduction}

With a nearly stabilized global fish production from capture, aquaculture has in recent times increased significantly throughout the world [1] and in most developing countries like Ghana. Aquaculture began in Ghana in 1950 [2] but only over the past two decades has the industry grown significantly, through the establishment of many fish farms across the country. Ghana's fish output from culture has expanded at an average annual growth rate of $50 \%$ since 2004, and is gradually making up for the deficit of over $50 \%$ between domestic fish demand and supply [3]. Aquaculture, mainly fish farming in Ghana is primarily based on Nile tilapia and $90 \%$ of the reported volume is raised in cages on the Volta Lake [3]. The cage system is gradually replacing the traditional fishgrowing method of earthen ponds in Ghana due to advantages such as relatively lower investment requirement, easier start up, and so forth that are well catalogued [4]-[6].

However, a major challenge that continually limits the scale up commercialization of tilapia cage culture in Ghana is a lack of reliable quantity and quality fingerlings for stocking in grow-out facilities [7]-[10]. Availability of quality seeds is very important because the lack of it can reduce a farm enterprise to a monumental waste and consequently discourage further financial investments in cage culture [11]. Although the growth in cage farming has stimulated an increase in the establishment of hatcheries along the Volta Lake [6] [10], the current supply of Nile tilapia fingerlings does not meet farm demands and an estimated 50 million seeds are lacking annually [10].

As a practice, Nile tilapia fingerlings are generally stocked as $20-40 \mathrm{~g}$ fingerlings in Ghana [6] due to the comparatively larger mesh size of production cages. However, due to an inadequate seed supply, competition, and the expensive nature of transporting such fingerlings than smaller fry, farmers are now forced to procure small fry ( $0.5-3 \mathrm{~g})$ and nurse to juvenile sizes $(25-40 \mathrm{~g})$ in nylon hapa cages although the process can be tricky. Nursing fry in nylon hapas is one of the best options, especially in Lakes and are the most favourable because they are relatively simple to sew, easy to wash and replace, easily available, inexpensive, and enables closer monitoring and grading results in uniform size harvest and better survival [4] [11]. Moreover, fingerlings subjected to pregrow-out nursery systems in hapas can easily adapt to the Lake environment and show better performance in growth and survival than those stocked directly from ponds into the grow-out cages [12].

Nursing fry in hapas is nevertheless subjected to the effects of stocking densities and ecological problems inherent in the system. The effect of stocking density on growth 
and fingerling production in Nile tilapia, has been studied by several authors [13]-[23] with varied results. It is generally accepted that growth performance and survival rate of fish tend to be inversely related to stocking densities and is mainly attributed to social interactions [20] [21]. However, in some cases, such an advantage of lower stocking densities is either non-existent [24] or temporary and wanes after sometime so that generally no differences occur across different stocking densities.

Increasing stocking density results in stress which leads to enhanced energy requirements causing reduced growth and food utilization [25] [26]. However, increasing it to a certain level may enhance total fish yield and lead to higher gross and net return at a lower cost of production [20] [21] [27]. Moreover, where land, water, manpower and other facilities are limiting it may be more profitable to adopt higher stocking densities [28]. On the contrary, reducing stocking densities ensures better fish growth [13]-[16] but may not always be favorable for commercial culture [11]. Proper management of stocking densities can therefore improve the growth, profitability, sustainability, health as well as reduce competition among fingerlings for food, space and other essentials of survival [29]. Therefore identifying and recommending the ideal fingerlings stocking densities in time is important to minimize cage production deficiencies in Ghana, where limited efforts have been devoted and performance data is even scarcer. The specific objectives of this study were:

To compare the growth (daily weight gain (DWG), specific growth rate (SGR) and growth homogeneity) and survival of fish cultured different stocking densities.

To investigate the effects of stocking density on feed conversion ratios (FCR) and profitability of Nile tilapia fingerlings stocked in hapas.

\section{Materials and Methods}

\subsection{Study Site}

The hapa cages were constructed and mounted in stratum II of the Volta Lake near the premises of Aquaculture Research and Development Center of the Water Research Institute in Akosombo, Ghana ( $06^{\circ} 16.996, \mathrm{E} 000^{\circ}$ 03.562). The Lake has a mean depth of $19 \mathrm{~m}$, a surface area of about $8500 \mathrm{~km}^{2}$ and a volume of $149 \mathrm{~km}^{3}$ at maximum level [30]. There are two rainy seasons in this portion of the Lake extending from May to October, followed by a prolonged dry season. This study was conducted between December 2012 and March 2013.

\subsection{Research and Experimental Design}

The study involved stocking Nile tilapia fry at different stocking densities and maintaining uniform management practices for a period of 84 days. Data was collected bi-weekly to assess impact of stocking density on survival, growth and profitability of fingerlings.

\subsection{Stocking and Feeding}

The Sex reversed Nile tilapia fry $(2.12 \pm 0.14 \mathrm{~g})$ were manually selected from earthen 
ponds, and randomly stocked in $1 \mathrm{~m}^{3}$ hapa cages at three stocking densities of 400 fish/hapa (T1), 800 fish/hapa (T2) and 1200 fish/hapa (T3). Each stocking were made in triplicate. The hapas were rectangular of synthetic netting of mesh size $1.5 \mathrm{~mm}$ and closed from all sides except the top. After stocking, fish were fed with a $38 \%$ crude protein commercial feed (Raanan) five times a day at an initial rate of $12 \%$ of their body weight for the first 2 weeks, then $10 \%$ from weeks 4 to 9 and finally adjusted to $7 \%$ from week 10 to the end of the trial period, following the standard of [31].

\subsection{Sampling and Growth Parameters}

Sampling was done bi-weekly to assess the growth performance of the fingerlings. Random samples of 50 fish from each hapa were weighed individually. Moreover, the final weight (g), specific growth rate (SGR), feed conversion ratio (FCR), coefficient of variation $(\mathrm{CV})$ and survival rate of fingerlings were calculated at the end of trial period.

The following parameters were used to evaluate the growth performance of fry:

$$
\begin{aligned}
& \text { Weight gain }(\mathrm{g})=\text { Mean final weight }- \text { Mean initial weight } \\
& \text { SGR (\%/day) }=(\text { In final weight }- \text { In initial weight }) 100 \mathrm{t}^{-1} \\
& \text { FCR = dry weight of feed consumed }(\mathrm{g}) / \text { wet weight gain }(\mathrm{g}) \\
& \text { Survival }(\%)=\text { No. of fish harvested/No. of fish stocked } \times 100
\end{aligned}
$$

The biomass was calculated as the product of the average final weight and the total number of survivors. A simple economic analysis was used to estimate the profitability in each treatment. The cost of feed, fingerlings and total revenue generated from harvest were estimated.

Profit index $=$ value of fish crop/total cost of feed [32].

\subsection{Water Quality Measurement}

Water quality parameters such as temperature, $\mathrm{pH}$ and dissolved oxygen were monitored. Ammonia was measured using the direct nesslerization method, Nitrite using the diazotization method and Hydrazine reduction method for Nitrate. The Ethylenediaminetetra acetic acid (EDTA) Titrimetric method was used in determining the total hardness and phosphate was determined by stannous chloride method. Temperature was recorded using Celsius thermometer; $\mathrm{pH}$ and dissolved oxygen (DO) were measured by a portable digital $\mathrm{pH}$ and $\mathrm{DO}$ meters respectively.

\subsection{Statistical Analysis}

Data was subjected to one-way analysis of variance (ANOVA) and when ANOVA indicated that there was a statistical difference between the stockings densities means, Tukeys tests were used to compare these means to determine whether significant difference existed between the different treatments and the parameters tested at $5 \%$ level of significance. 


\section{Results}

The growth curves showed a gradual growth of fingerlings from the start to the end of experiment (Figure 1). The growth performance indicators and survival rate of fingerlings cultured at the three treatments are shown in Table 1. From the analysis, significant differences ( $\mathrm{p} \leq 0.05)$ were observed among the different treatment groups and T1 showed the best performance in growth parameters studied, namely; final weight gain $(33.54 \pm 0.66 \mathrm{~g})$ and specific growth rate $(3.28 \pm 0.10 \% /$ day $)$. The SGR was significant $(\mathrm{p}<0.05)$ between the treatment groups although, rates for treatment T2 $(3.13 \pm$ $0.05)$ and T3 $(2.86 \pm 0.15)$ were similar.

The values of feed conversion ratio (FCR) increased with increasing stocking density. FCR were significantly $(\mathrm{p}<0.05)$ different for fingerling stocked in all treatments except for T2 and T3. The best FCR was observed in T1 (1.42 \pm 0.09$)$ whereas the highest was recorded in T3 $(2.07 \pm 0.14)$. Survival and recovery was generally high in all treatments with rates ranging from $89 \%$ to $91 \%$. Although among T1, T2 and T3, there were no observed significant differences at $\mathrm{p}>0.05$, the highest survival rate was recorded in the T3 (91.14 \pm 3.23$)$ while the lowest was observed in T2 (89.29 \pm 0.64$)$. The different stocking densities did not significantly affect the CV of fish in all treatments (Table 1).

A summary of the mean values of water quality parameters recorded during stocking and throughout the culture period is presented in Table 2. All the parameters measured

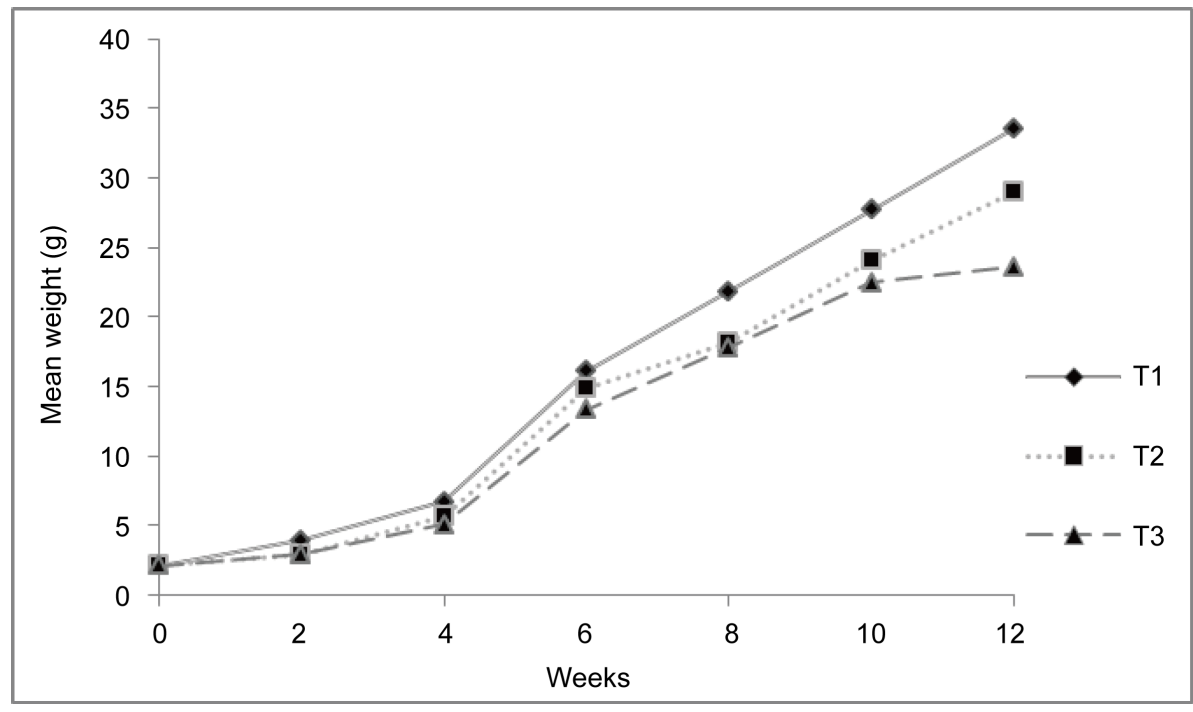

Figure 1. Growth of $O$. niloticus fingerlings cultured for 12 weeks at three stocking densities.

Table 1. Growth of $O$. niloticus fingerlings cultured for 12 weeks at three stocking densities.

\begin{tabular}{|c|c|c|c|c|c|c|c|}
\hline Treatments & Av. initial wt (g) & Av. final wt (g) & Av. weight gain (g) & SGR (\%/day) & FCR & CV (\%) & Survival (\%) \\
\hline T2 (800/hapa) & $2.09 \pm 0.06^{\mathrm{a}}$ & $29.03 \pm 1.01^{\mathrm{ab}}$ & $26.95 \pm 0.99^{\mathrm{ab}}$ & $3.13 \pm 0.05^{\mathrm{bc}}$ & $1.72 \pm 0.09^{b c}$ & $37.08 \pm 1.28^{\mathrm{a}}$ & $89.29 \pm 0.64^{\mathrm{a}}$ \\
\hline T3 (1200/hapa) & $2.15 \pm 0.23^{\mathrm{a}}$ & $23.63 \pm 2.14^{c}$ & $21.49 \pm 2.09^{c}$ & $2.86 \pm 0.15^{\mathrm{c}}$ & $2.07 \pm 0.14^{\mathrm{c}}$ & $41.33 \pm 1.73^{\mathrm{a}}$ & $91.14 \pm 3.23^{\mathrm{a}}$ \\
\hline
\end{tabular}

Mean values in the column with different superscripts are significantly different. 
Table 2. Mean $( \pm \mathrm{SE})$ values of water quality parameters in the hapa cages during culture.

\begin{tabular}{|c|c|c|c|c|c|c|c|c|c|}
\hline Parameters & Temperature $\left({ }^{\circ} \mathrm{C}\right)$ & $\mathrm{pH}$ & \multicolumn{7}{|c|}{ Concentration (mg/l) } \\
\hline Culture & $27.3 \pm 0.19$ & $6.70 \pm 0.04$ & $28.53 \pm 0.09$ & $24.00 \pm 0.23$ & $4.11 \pm 0.18$ & $0.04 \pm 0.00$ & $0.004 \pm 0.000$ & $0.05 \pm 0.01$ & $0.03 \pm 0.01$ \\
\hline
\end{tabular}

reflect the environmental conditions under which the fish were cultured and were within the optimal range for tilapia growth.

As shown in Table 3, fish biomass as well as the value of fish crop increased with increasing stocking densities. The highest value of juvenile fish crop was found in T3 ( GHథ $295.29 \pm 10.47$ ) while the lowest value was recorded in T1 ( $\mathrm{GH} \$ 98.37 \pm 0.91$ ). Significant differences $(\mathrm{p}<0.05)$ were found in the calculated profit index among the treatment groups. Treatment T3 attained the highest value of (3.96 \pm 0.24$)$ followed by $\mathrm{T} 2$ and $\mathrm{T} 1$ with values of $2.46 \pm 0.07$ and $1.31 \pm 0.10$ respectively.

\section{Discussions}

With an increasing need of Nile tilapia seeds by cage operators in Ghana, various strategies are being practiced with the aim of obtaining profits. Lake-based nursing of fry in hapa cages is one of them. However, stocking density affects this technique in terms of fry growth performance, survival and economic profitability. In the present study, significant differences are found among the growth parameters of the three treatments. This complies with [11] [23] [28] [29] and [33], who also found similar effects of stocking density.

Treatment 1 with a stocking density of 400 fish per hapa was most favorable and found all the growth parameters like final weight, FCR and SGR best. Reference [15] confirmed that increasing the number of fish (density) will adversely affect fish growth. Additionally, [34] also proved that the least stocking rate attained the highest final weight, weight gain, SGR, feed conversion, and protein efficiency ratio for Oreochromis niloticus. The lower growth performance of tilapia at higher stocking density could have been caused by voluntary appetite suppression, more expenditure of energy because of antagonistic behavioral interaction, competition for food and living space [35] and increased stress [36].

In commercial production of Nile tilapia, an increase in stocking density will also increase net profit with the same unit area and resources. But in small scale farming, not only profit but investment capability also needs to be taken into consideration [11]. In the present study, although growth rate is found best in lowest stocking density (T1), it is not commercially feasible because of low profit index which was affected significantly by stocking density. This agrees with [24] who found significant differences $(\mathrm{p}<0.05)$ in the profit index for Nile tilapia, reared at different densities. Treatment T3 with a stocking rate of 1200/hapa was most profitable with an index of $3.96 \pm 0.24$.

A major drawback for fish production during the nursery phase is differential 
Table 3. A simple economic analysis for profitability among the treatment groups.

\begin{tabular}{ccccccc}
\hline Treatments & $\begin{array}{c}\text { Fingerlings cost } \\
(\mathrm{GH})\end{array}$ & Feed applied (kg) & Feed cost (GHథ) & Biomass (kg) & $\begin{array}{c}\text { Value of fish cropped } \\
(\mathrm{GH})\end{array}$ & Profit index \\
\hline T1 (400/hapa) & 48.00 & 44.00 & 75.82 & $12.22 \pm 0.32$ & $98.37 \pm 0.91$ & $1.31 \pm 0.10^{\mathrm{a}}$ \\
T2 (800/hapa) & 96.00 & 46.00 & 78.43 & $20.75 \pm 0.86$ & $192.87 \pm 1.37$ & $2.46 \pm 0.07^{\mathrm{b}}$ \\
T3 (1200/hapa) & 144.00 & 44.00 & 74.80 & $25.75 \pm 2.01$ & $295.29 \pm 10.47$ & $3.96 \pm 0.24^{\mathrm{c}}$ \\
\hline
\end{tabular}

Mean values in the column with different superscripts are significantly different.

growth. Economically, harvest and sales of uniformly sized fingerlings is preferred to differential sizes. The tested stocking densities in this study did not significantly ( $p>$ 0.05) affect the weight variations of the fish unlike [37] who found some significant effect on final $\mathrm{CV}$ in their trial with Florida red tilapia in marine cages.

Feed conversion ratio, FCR in this study was significantly affected by stocking density as was the case of [29] and [24] although differences in the 800/hapa and 1200/hapa treatments were similar. The best FCR was realized in T1 (1.42) and could be attributed to effective feed utilization which was reflected in the growth rate. The realized increase in FCR with higher stocking densities is in conformity with results obtained by [38] and [29]. Although feed intake and utilization by fish in treatment T3 was observed to be very low $(44 \mathrm{~kg}$ ), it still recorded the worst FCR of 2.07. This can be explained by the fact that efficient utilization of diets can vary even within a single species because of the highly densed interactions and inherent environmental factors [39].

All the physical-chemical parameters of the water in the cages were within the acceptable optimal range for fish culture. The water quality parameters recorded were within the acceptable ranges as recommended for tropical aquaculture [40] [41] and therefore did not affect the culture of fish.

\section{Conclusion}

Optimum utilization of space for maximum production in intensive fish culture practices is known to improve the profitability of fish farms. In this study, it is revealed that increasing the stocking density of Nile tilapia fingerlings significantly affects growth, feed conversion, profitability and yield of tilapia fingerlings reared in Lake-based hapas.

\section{Acknowledgements}

The authors are grateful for the support received from management and staff of the Aquaculture Research and Development Centre (ARDEC). Support from the Danish Government through the University of Ghana under "Building Stronger Universities" project is also acknowledged.

\section{References}

[1] Food and Agriculture Organization, FAO (2016) The State of World Fisheries and Aquaculture 2016. Contributing to Food Security and Nutrition for All. Rome, 200 p. 
[2] Alshihhi, J.M.A. (2013) Construction of a Spatial Database of Aqua-Farms in Ghana and Identification of Locations for Future Developments of the Sector. Institute of Aquaculture, University of Stirling, Stirling.

[3] Frimpong, E. A., and Fynn, I.E.M. (2014) Tilapia Aquaculture in Ghana: Ponds Can Contribute More to Overall Production, Food Security. Global Aquaculture Advocate, 38-41.

[4] Blow, P. and Shivaon, L. (2005) A Review of Cage Aquaculture: Sub-Saharan Africa. Regional Reviews and Global Overview. FAO Fisheries Technical Paper, 498, 188-207.

[5] Halwart, M., Soto, D. and Arthur, J.R. (2007) Cage Aquaculture Regional Reviews and Global Overview. FAO Fisheries Technical Paper, 498, 241 p.

[6] Ofori, J.K., Dankwa, H.R., Brummett, R. and Abban, E.K. (2009) Producing Tilapia in Small Cage in West Africa. World Fish Center Technical Manual, 1952, 16.

[7] Asmah, R. (2008) Development Potential and Financial Viability of Fish Farming in Ghana. PhD Dissertation, Institute of Aquaculture, University of Stirling, Stirling.

[8] Frimpong, S.K. and Adwani, A. (2015) The Challenges and Prospects of Fish Farming in Ghana : A Project Management Perspective. International Journal of ICT and Management, 3, 29-34.

[9] Hiheglo, P.K. (2008) Aquaculture in Ghana: Prospects, Challenges, Antidotes and Future Perspectives. Master Thesis, International Fisheries Management, University of Tromso, Norway. http://munin.uit.no/handle/10037/1431

[10] Rurangwa, E., Agyakwah, S.K., Boon, H. and Bolman, B. (2015) Business Cases for Aquaculture Investment in Ghana. Development of Aquaculture in Ghana. Analysis of the Fish Value Chain and Potential Business Cases. IMARES Report C021/15, March, 1-9.

[11] Kunda, M., Harun-al-Rashid, A., Morshed, F., Islam, A. and Mazumder, S.K. (2014) Production of Tilapia (Oreochromis niloticus ) Fingerling in Hapa Using Swim-Up Fry Involving Women in the Haor Region of Bangladesh. IOSR Journal of Agriculture and Veterinary Science, 7, 2319-2380. http://dx.doi.org/10.9790/2380-071012935

[12] Mensah, E.T.D., Atipoe, F.K.Y. and Atsakpo, K. (2014) Comparative Growth Study of Oreochromis niloticus and Sarotherodon galilaeus under Two Different Culture Regimes (Hapa-in-Pond and Cage Systems). International Journal of Fisheries and Aquatic Studies, 1, 53-59.

[13] Ridha, M.T. (2005) Comparative Study of Growth Performance of Three Strains of Nile Tilapia, Oreochromis niloticus, L. at Two Stocking Densities. Aquaculture Research, 37, 172 179. http://dx.doi.org/10.1111/j.1365-2109.2005.01415.x

[14] Al-Harbi, A.H. and Siddiqui, A.Q. (2000) Effects of Tilapia Stocking Densities on Fish Growth and Water Quality in Tanks. Asian Fisheries Science, 13, 391-396.

[15] Yousif, O.M. (2002) The Effects of Stocking Density, Water Exchange Rate, Feeding Frequency and Grading on Size Hierarchy Development in Juvenile Nile Tilapia, Oreochromis niloticus. Emirates Journal of Agriculture Science, 14, 45-53. http://dx.doi.org/10.9755/ejfa.v14i1.4984

[16] Abdel-Tawwab, M., Mousa, M.M.A., Sharaf, S.M. and Ahmed, M.H. (2005) Effect of Crowding Stress on Some Physiological Functions of Nile Tilapia, (Oreochromis niloticus L) Fed Different Dietary Protein Levels. International Journal of Zoological Research, 1, 4147. http://dx.doi.org/10.3923/ijzr.2005.41.47

[17] Osofero, A., Otubusin, S.O. and Daramola, J.A. (2007) Effect of Stocking Density on Tilapia (Oreochromis niloticus Linnaeus 1757) Growth and Survival in Bamboo-Net Cages Trial. Journal of Fisheries International, 2, 182-185. 
[18] Khalfalla, M.M., Hammouda, Y.A., Tahoun, A.M. and Abo-State, H.A.M. (2008) Effect of Brood Stock on Growth and Reproductive Performance of Blue Tilapia Oreochromis aureus (Steindachner) Reared in Hapas. The 8 th International Symposium on Tilapia in Aquaculture, Cairo, 12-14 October 2008, 115-125.

[19] Offem, B.O., Gabriel, U.I. and Ayotunde, E.O. (2009) Effect of Stocking Size of the Predatory African Catfish (Heterobranchus longifilis V.) on the Growth Performance of Nile Tilapia (Oreochromis niloticus L.) in Pond Culture. International Journal of Fisheries and Aquaculture, 1, 38-43.

[20] Onumah, E.E., Wessels, S., Wildenhayn, N., Brummer, B. and Schwark, G.H. (2010) Stocking Density and Photoperiod Manipulation in Relation to Estradiol Profile to Enhance Spawning Activity in Female Nile Tilapia. Turkish Journal of Fisheries and Aquatic Sciences, 10, 463-470.

[21] Chakraborty, S.B. and Banerjee, S. (2010) Effect of Stocking Density on Monosex Nile Tilapia Growth during Pond Culture in India. World Academy of Science, Engineering and Technology, 44, 1521-1525.

[22] Mensah, E.T.-D., Attipoe, F.K. and Ashun-Johnson, M. (2013) Effect of Different Stocking Densities on Growth Performance and Profitability of Oreochromis niloticus Fry Reared in Hapa-in-Pond System. International Journal of Fisheries and Aquaculture, 5, 204-209.

[23] Fedous, Z., Masum, Md.A. and Ali, Md.M. (2014) Influence of Stocking Density on Growth Performance and Survival of Monosex Tilapia (Oreochromis niloticus) Fry. International Journal of Research in Fisheries and Aquaculture, 4, 99-103.

[24] Osofero, S.A., Otubusin, S.O. and Daramola, J.A. (2009) Effect of Stocking Density on Tilapia (Oreochromis niloticus, Linnaeus 1757) Growth and Survival in Bamboo-Net Cages Trial. African Journal of Biotechnology, 8, 1322-1325.

[25] Leatherland, J.F. and Cho, C.Y. (1985) Effect of Rearing Density on Thyroid and Internal Gland Activity and Plasma Hepatic Metabolite Levels in Rainbow Trout, Salmo gairdneri, Richardson. Journal of Fisheries Biology, 27, 583-592. http://dx.doi.org/10.1111/j.1095-8649.1985.tb03203.x

[26] Hengsawat, K.H., Ward, F.J. and Jaruratjamorn, P. (1997) The Effect of Stocking Density on Yield, Growth and Mortality of African Catfish (Clarias gariepinus Burchell 1822) Cultured in Cages. Aquaculture, 152, 67-76. http://dx.doi.org/10.1016/S0044-8486(97)00008-2

[27] Abou, Y., Fiogbe, E.D. and Micha, J.C. (2007) Effects of Stocking Density on Growth, Yield and Profitability of Farming Nile Tilapia, Oreochromis niloticus L., Fed Azolla Diet, in Earthen Ponds. Aquaculture Research, 38, 595-604. http://dx.doi.org/10.1111/j.1365-2109.2007.01700.x

[28] Ridha, M.T. (2005) Comparative Study of Growth Performance of Three Strains of Nile Tilapia, Oreochromis niloticus, L. at Two Stocking Densities. Aquaculture Research, 37, 172 179. http://dx.doi.org/10.1111/j.1365-2109.2005.01415.x

[29] Gibtan, A., Getahun, A. and Mengistou, S. (2008) Effect of Stocking Density on the Growth Performance and Yield of Nile Tilapia [Oreochromis niloticus (L., 1758)] in a Cage Culture System in Lake Kuriftu, Ethiopia. Aquaculture Research, 39, 1450-1460. http://dx.doi.org/10.1111/j.1365-2109.2008.02021.x

[30] Rodgers, C., van de Giesen, N., Laube, W. and Youkhana, E. (2007) The GLOWA Volta Project: A Framework for Water Resources Decision-Making and Scientific Capacity Building in a Transnational West African Basin. In: Craswell, E., Bonnell, M., Bossio, D., Demuth, S. and Van De Giesen, N., Eds., Integrated Assessment of Water Resources and Global Change: A North-South Analysis, Springer, The Netherlands, 295-313. http://dx.doi.org/10.1007/978-1-4020-5591-1_18 
[31] Nandlal, S. and Pickering, T. (2004) Tilapia Fish Farming in Pacific Island Countries. Tilapia Hatchery Operation. Secretariat of the Pacific Community, Noumea, New Caledonia, 190-203.

[32] Ita, E.O. and Okeoye, C. (1988) Preliminary Comparison of the Growth Performance of All-Male, All Female and Mixed Population of Oreochromis niloticus in Hapa Net in Fertilized Concrete Ponds. Annual Report, National Institute for Freshwater Fisheries Research.

[33] Huang, W.B. and Chiu, T.S. (1997) Effects of Stocking Density on Survival, Growth, Size Variation, and Production of Tilapia Fry. Aquaculture Research, 28, 165-173.

[34] Barcellos, L.J.G., Nicolaiewsky, S., Souza, S.M.G. and Lulhier, F. (1999) Plasmatic Levels of Cortisol in the Response to Acute Stress in Nile Tilapia, Oreochromis niloticus (L.), Previously Exposed to Chronic Stress. Aquaculture Research, 30, 437-444. http://dx.doi.org/10.1046/j.1365-2109.1999.00348.x

[35] Kheir, M.T. and Saad, A.S. (2003) Growth Performance and Feed Utilization of Oreochromis niloticus (Linnaeus, 1757) Fingerlings as Affected with Stocking Density and Feeding Regime. Journal of Egyptian Academy, Social and Environmental Development (B-Aquaculture), 4, 1-21.

[36] Diana, J.S., Yi, Y. and Lin, C.K. (2004) Stocking Densities and Fertilization Regimes for Nile Tilapia (Oreochromis niloticus) Production in Ponds with Supplemental Feeding. In: Bolivar, R., Mair, G. and Fitzsimmons, K., Eds., Proceedings of the 6 th International Symposium on Tilapia in Aquaculture Manila, BFA Philippines, Philippines, 487-499.

[37] Ouattara, N., Teugels, G., Douba, V. and Philippart, J. (2003) Aquaculture Potential of the Black-Chinned Tilapia, Sarotherodon melanotheron (Chiclidae). Comparative Study of the Effect of Stocking Density on Growth Performance of Landlocked and Natural Populations under Cage Culture Conditions in Lake Ayame (Côte d'Ivoire). Aquaculture Research, 34, 1223-1229. http://dx.doi.org/10.1046/j.1365-2109.2003.00921.x

[38] Watanabe, W.O., Clark, J.H., Dunkham, J.B., Wicklund, R.I. and Olla, B.L. (1990) Culture of Florida Red Tilapia in Marine Cages: The Effects of Stocking Density and Dietary Protein on Growth. Aquaculture, 90, 123-134. http://dx.doi.org/10.1016/0044-8486(90)90336-L

[39] Ellis, T., North, B., Scott, A.P., Bromage, N.R., Porter, M. and Gadd, D. (2002) The Relationships between Stocking Density and Welfare in Farmed Rainbow Trout. Journal of Fish Biology, 61, 493-531. http://dx.doi.org/10.1111/j.1095-8649.2002.tb00893.x

[40] Boyd, C.E. (1982) Water Quality Management for Pond Fish Culture. Elsevier, Amsterdam, 318.

[41] Beveridge, M.C.M. (1996) Cage Aquaculture. 2nd Edition, Fishing News, Oxford, 346. 
Submit or recommend next manuscript to SCIRP and we will provide best service for you:

Accepting pre-submission inquiries through Email, Facebook, LinkedIn, Twitter, etc. A wide selection of journals (inclusive of 9 subjects, more than 200 journals)

Providing 24-hour high-quality service

User-friendly online submission system

Fair and swift peer-review system

Efficient typesetting and proofreading procedure

Display of the result of downloads and visits, as well as the number of cited articles

Maximum dissemination of your research work

Submit your manuscript at: http://papersubmission.scirp.org/

Or contact as@scirp.org 